of water that fall on the border are currently under Israeli control. International water law would see this change to a roughly 60:40 split in Israel's favour.

Another source of conflict is the Joint Water Committee, set up under Oslo II (J. Selby Rev. Int. Stud. 29, 121-138; 2003). By creating a bargaining market, it has stifled investment in and management of the Palestinian water sector (see go.nature.com/ gxdPWB).

For example, Israeli approval of Palestinian water projects is contingent on Palestinian approval of projects for the encroaching illegal settlements. When such projects are refused by the Palestinian side, the Israeli side denies internationally sponsored development projects destined for Palestinian towns. The Palestinian Water Authority's credibility is eroded with each settlement it legitimizes, and anger mounts as violations pile up (see go.nature.com/714REE).

Establishing a more effective joint committee is best done using a new agreement that ensures fair allocations. The basis for resolving the conflict could come from Israel's desalination plants and from reallocating water away from its exported water-intensive commodities, both of which would relieve pressure on freshwater supplies.

Negotiators and mediators who fail to push for this makeover will be perpetuating, not resolving, the water conflict. Mark Zeitoun University of East Anglia, UK, m.zeitoun@uea.ac.uk

\section{More outreach for young scientists}

Initiatives such as the European Union's Science in Society programme (see go.nature.com/ MZdJua) spend millions on projects that aim to bring the scientific community closer to the public and the media. We believe it should be easier for young scientists in particular to contribute to such efforts.

To this end, we organized a symposium ('Scientist! Come out of your lab!') in April 2010.
There it was apparent that our fellow $\mathrm{PhD}$ students were keen to be involved in social and educational projects, but were unclear about how to put their enthusiasm into practice.

One way would be for mentors of young scientists to encourage them to take 'societal breaks' to pursue such initiatives similar to the innovation breaks' of Google's employees. Funding these small grassroots projects would be inexpensive for programmes run by the European Union and others. Caroline J. Aalbers, Justus L. Groen, Suthesh Sivapalaratnam Academic Medical Center, University of Amsterdam, the Netherlands,

c.j.aalbers@amc.uva.nl

\section{Disclose all data in publications}

After thousands of hours of investigation, three clinical trials at Duke University in Durham,

North Carolina, were suspended in late 2009 because of the irreproducibility of the genomic 'signatures' used to select cancer therapies for patients. Journals have a duty to help the community by maintaining reproducibility as a cornerstone of the scientific process.

The independent reanalysis of these signatures took so long because the information accompanying the associated publications was incomplete. Unfortunately, this is common: for example, a survey of 18 published microarray geneexpression analyses found that the results of only two were exactly reproducible (J. P. Ioannidis et al. Nature Genet. 41, 149-155; 2009). Inadequate information meant that 10 could not be reproduced.

To counter this problem, journals should demand that authors submit sufficient detail for the independent assessment of their paper's conclusions. We recommend that all primary data are backed up with adequate documentation and sample annotation; all primary data sources, such as database accessions or URL links, are presented; and all scripts and software source codes are supplied, with instructions. Analytical (non-scriptable) protocols should be described step by step, and the research protocol, including any plans for research and analysis, should be provided (see go.nature.com/ UaF2Kv). Files containing such information could be stored as supplements by the journal.

There may be some situations that preclude authors from supplying complete data or code - in protecting patient confidentiality, for example. In such cases, authors should justify the omission and assure independent reproducibility by alternative means.

The quality of scientific output will benefit from setting these standards. As a community, we owe it to patients and to the public to do what we can to ensure the validity of the research we publish.

Keith Baggerly on behalf of 7 co-authors ${ }^{*}$, The University of Texas MD Anderson Cancer Center, USA,

kabagger@mdanderson.org

${ }^{*}$ A full list of signatories is available online at $h t t p: / / d x$.doi. org/10.1038/467401b

\section{Why the inaction on biodiversity?}

We are launching an initiative to assess whether or not decisionmakers are serious about wanting to halt the biodiversity crisis (S. H. M. Butchart et al. Science 328, 1164-1168; 2010).

It is not clear why efforts to stem the loss of biodiversity have so far been disappointing. Is it because of ineffective communication from scientists? Or is it because governments are unwilling to listen to troublesome scientific recommendations?

To find out, we are collating a list of conservation actions needed in the G20 countries. The actions must be justified by unequivocal peer-reviewed research findings; supported by the community of conservation scientists; help to preserve or restore an endangered species or ecosystem; be politically costly to implement because they are opposed by some interest groups; and be specific, measurable, attainable, realistic and timely (see go.nature.com/DTkV9T).

With support from UK newspaper The Guardian, we shall approach all G20 governments at the October meeting of the Convention on Biological Diversity in Nagoya, Japan, asking them to implement these tasks and to avoid the 2010 International Year of Biodiversity being a celebration of failure.

If you have published peerreviewed research that has met opposition in influencing biodiversity policy, please contact us.

Guillaume Chapron Swedish University of Agricultural Sciences, Sweden, guillaume.chapron@ekol.slu.se Raphaël Arlettaz University of Bern, Switzerland

Luigi Boitani Università di Roma La Sapienza, Italy

\section{DNA dealt wrong hand on cover}

It could not escape my notice that your cover of 9 September (Nature 467, issue 7312; 2010) is dominated by a DNA molecule with a pronounced left-handed helical twist. In the structure originally proposed by James Watson and Francis Crick in your pages, however, the chains of DNA follow paired righthanded helices.

I suggest that this sketch of DNA, arguably the most iconic image ever published by Nature, be displayed prominently in your offices to prevent such unfortunate howlers being made in future.

Michael Eisen Howard Hughes Medical Institute, University of California, Berkeley, USA, mbeisen@berkeley.edu

\section{CONTRIBUTIONS}

Submissions to Correspondence should be sent to correspondence@ nature.com after consulting the author guidelines at http://go.nature.com/ cMCHno. 